\title{
Faktor-Faktor Personal Sebagai Prediktor Terhadap Resiliensi Perawat Di Rumah Sakit Penyakit Infeksi Prof. Dr. Sulianti Saroso
}

\author{
Barita Ulina Mariani \\ Rumah Sakit Penyakit Infeksi Prof. Dr. Sulianti Saroso
}

\begin{abstract}
Abstrak. Daya tahan seorang perawat dalam menghadapi tuntutan pekerjaan dan tanggung jawabnya dalam merawat pasien di rumah sakit sangatlah diperlukan, agar seorang perawat dapat menyeimbangkan antara kinerja, masalah sehari-hari, dan beban pekerjaan yang dihadapi hampir setiap hari di dalam kehidupannya. Daya tahan yang dimaksud adalah resiliensi. Begitu pentingnya resiliensi bagi seorang perawat, namun, kajian maupun penelitian mengenai resiliensi pada perawat di RSPI-SS belum ada. Begitu juga dengan faktor-faktor yang mempengaruhi resiliensi tersebut.

Tulisan ini bertujuan untuk melihat gambaran tingkat resiliensi perawat dan prediktor resiliensi pada perawat di Rumah Sakit Sulianti Saroso pada semua ruangan dan bangsal yang langsung menangani pasien, khususnya pada pasien HIV AIDS. Populasi penelitian adalah para perawat di rumah sakit Prof. Dr. Sulianti Saroso, sedangkan sampel penelitian adalah perawat-perawat yang secara langsung merawat pasien. Teknik pengambilan sampel dilakukan secara random. Untuk mengetahui tingkat resiliensi, self efficacy, hope, dan coping serta keterkaitan antara variabel, dilakukan pengumpulan data dengan menggunakan instrument penelitian yakni skala resiliensi, skala self efficacy, skala hope, dan skala strategi coping yang disusun sendiri oleh peneliti dan tim. Hasil penelitian menunjukkan tingkat resiliensi pada perawat di RSPI-SS berada pada level sedang. self efficacy dan hope terbukti merupakan prediktor terhadap resiliensi pada perawat,
\end{abstract}

Kata Kunci : Prediktor resiliensi, resiliensi, self efficacy, hope, strategi coping, perawat

Korespondensi : Barita Ulina Mariani, RSPI Prof. Dr. Sulianti SarosoJl. Baru Sunter Permai, Papanggo Tanjung Priok, Jakarta Utara Telp : (021) 6506559 ext.2004, e-mail : baritaulina@yahoo.co.id

\section{PENDAHULUAN}

$\begin{array}{lll}\text { Setiap manusia pasti } & \text { pernah } \\ \text { mengalami masalah di } & \text { dalam } \\ \text { kehidupannya. Manusia bisa } & \text { marah, }\end{array}$ sedih, kecewa, dan sebagainya, ketika dihadapkan kepada suatu masalah atau persoalan. Tetapi manusia harus memiliki suatu kekuatan di dalam dirinya yang membuat dirinya bertahan hidup walau ditempa banyak masalah. Kekuatan tersebut disebut dengan Resiliensi.

Perawat, sebagai salah satu profesi yang bekerja di sebuah institusi kesehatan atau rumah sakit, seperti manusia lainnya, juga bisa menghadapi banyak masalah, baik dalam pekerjaan, keluarga, dan kehidupan sosialnya.

Tugas yang mulia sebagai seorang perawat yang merawat orang sakit tetap harus diemban, tidak peduli penyakit yang diderita oleh pasien, dan tidak peduli resiko pekerjaan yang mungkin dihadapi serta seberat apapun tanggung jawab yang harus dipikul, seorang perawat dengan sepenuh hati dan segenap jiwa harus tetap melaksanakan tugasnya dengan baik.

Dalam kenyataan di lapangan, ternyata tidaklah mudah bagi perawat menjalankan perannya. Perawat dituntut totalitas dalam bekerja, juga harus mengesampingkan masalah pribadi yang mungkin dihadapi dalam waktu yang bersamaan. Pencetusnya bisa datang dari atasan, teman sekerja, manajemen, keuangan, penempatan kerja yang tidak sesuai dengan minat dan kemampuan, jarak tempuh rumah dengan tempat kerja yang 
cukup jauh, masalah keluarga dan sebagainya.

Beberapa kendala lain yang mungkin dihadapi perawat di dalam pekerjaan, khususnya perawat yang menangani penyakit-penyakit yang infeksius seperti di rumah sakit Sulianti Saroso, antara lain penyakit TB dan HIV, ialah menghadapi pasien yang tidak kooperatif, tidak mau menerima hasil tes yang positif menderita HIV, harus menjaga rahasia/status pasien walaupun mengenal pasien tersebut, belum lagi risiko tertusuk jarum penderita HIV dan terpajan penyakit TB maupun Hepatitis saat merawat pasien.

Semua masalah yang dihadapi tersebut menguras energi, pikiran, konsenterasi, kondisi kesehatan fisik dan psikologis perawat tersebut dalam berbagai bentuk, misalnya bersikap sinis dan acuh tak acuh kepada pasien, sering membolos, sering merasa pusing, ingin selalu pindah pekerjaan, serta apatis terhadap masa depan dirinya dan kondisi di dalam pekerjaannya. Menurut Persatuan Perawat Nasional Indonesia (PPNI, 2006) sebanyak 50,9\% perawat Indonesia yang bekerja mengalami stres kerja, sering merasa pusing, lelah, kurang ramah, kurang istirahat akibat beban kerja terlalu tinggi serta penghasilan yang tidak memadai ${ }^{24}$.

Hal ini sejalan dengan hasil wawancara awal pada Sembilan orang perawat di RSPI-SS yang menyatakan bahwa umumnya perawat kurang bersemangat dalam bekerja, kurang peduli terhadap pekerjaan, sakit-sakitan, dan sensitif terhadap perkataan orang lain.

Keadaan tersebut, kalau dibiarkan berlarut-larut maka akan menyebabkan perawat bisa mengalami masalah psikologis yang lebih berat dan ini bisa berdampak pada interaksi dengan karyawan lain, pekerjaan, dan institusi tentunya.

Dalam laporan UNAIDS tentang penatalaksanaan stres bagi perawat HIV/AIDS dinyatakan bahwa rasa frustasi bukanlah sebuah 'peristiwa' tetapi sebuah proses tekanan dan kecemasan yang dialami setiap hari yang tidak ditanggapi. Hal ini secara bertahap akan mengganggu kesehatan mental dan fisik perawat itu, sehingga pada akhirnya mengorbankan layanan dan hubungan pribadi. Dari hasil kajian Lance sheriif pada tahun 2009 menyatakan kurang lebih $21 \%$ petugas layanan kesehatan mengatakan mereka tidak peduli lagi terhadap apa yg terjadi pada pasien mereka. Salah seorang penulis bernama Freuden berger menyatakan bahwa stres demi stres yang dialami oleh seorang karyawan secara terus-menerus secara kronis akan menyebabkan orang tersebut mengalami perubahan motivasi, dan pada akhirnya bisa mengalami burnout ${ }^{25}$.

Agar hal tersebut tidak terjadi pada perawat, maka beban mental, beban psikologis, dan beban pekerjaan harus dapat dihadapi supaya tetap dapat bekerja dengan totalitas dan memiliki kinerja yang baik. Untuk itu, seorang perawat membutuhkan suatu kekuatan yang berasal dari dalam dirinya sendiri yang disebut dengan resiliensi.

Resiliensi tidak berdiri sendiri, tinggi rendahnya dipengaruhi oleh banyak faktor. Terdapat berbagai penelitian mengenai resiliensi, salah satunya penelitian yang dilakukan oleh Gillespie, mengenai prediktor resiliensi pada perawat di ruang operasi di Australia. Pada penelitian ini didapatkan variabel bebas seperti, Hope, Self Efficacy, managging stress dan kompetensi dalam sampel yang lebih besar dari ACORN responden $(n=124)$, Hope, Self Efficacy dan Strategi Coping merupakan prediktor resiliensi ${ }^{6}$. Namun, penelitian itu dilakukan kepada perawat khusus yang bekerja di ruangan Operasi. Sementara di Rumah Sakit Penyakit infeksi Prof.Dr.Sulianti Saroso, penelitian ini bertujuan melihat resiliensi dan prediktor-prediktor resiliensi pada perawat yang bertugas di semua ruangan rawat inap dan rawat jalan.

\section{TINJAUAN PUSTAKA}

\section{Resiliensi}

Grotberg $^{7}$ menyatakan bahwa resiliensi adalah kemampuan seseorang untuk menilai, mengatasi, dan meningkatkan diri ataupun mengubah dirinya dari keterpurukan atau kesengsaraan dalam hidup. Hal senada diungkapkan oleh 
Reivich dan Shatte, bahwa resiliensi adalah kapasitas untuk merespon secara sehat dan produktif ketika menghadapi kesulitan atau trauma, dimana hal itu penting untuk mengelola tekanan hidup sehari-hari. Resiliensi adalah kemampuan untuk beradaptasi dan tetap teguh dalam situasi sulit. Jadi, dapat disimpulkan bahwa dalam penelitian ini, yang dimaksud dengan resiliensi adalah kemampuan untuk beradaptasi (menyesuaikan diri) dengan cara meningkatkan dan mengelola diri sehingga dapat tetap teguh ketika menghadapi situasi sulit atau tekanan hidup sehari-hari ${ }^{15}$.

\section{Self Efficacy}

Bandura mengemukakan self efficacy sebagai keyakinan individu mengenai kemampuan dirinya dalam melakukan tugas atau tindakan yang diperlukan untuk mencapai hasil tertentu, self efficacy merupakan hasil dari proses kognitif berupa keputusan, keyakinan, tentang sejauh mana individu memperkirakan kemampuan dirinya dalam melaksanakan tugas atau tindakan tertentu dalam melaksanakan tugas atau tindakan tertentu yang diperlukan untuk mencapai hasil yang diinginkan. Lebih lanjut, dikatakan oleh Bandura dan Wood bahwa self efficacy mengacu pada keyakinan akan kemampuan individu untuk menggerakkan motivasi, kemampuan kognitif, dan tindakan yang diperlukan untuk memenuhi tuntutan situasi ${ }^{2}$.

Dalam penelitian ini definisi self efficacy adalah definisi menurut Bandura, yang menyatakan bahwa self efficacy adalah suatu keyakinan individu mengenai kemampuan dirinya dalam melakukan tugas atau tindakan yang diperlukan untuk mencapai hasil tertentu ${ }^{1,2}$.

\section{Coping}

Adapun pengertian coping dari masingmasing ahli psikologi berbeda-beda, salah satunya Folkman dan Lazarus menyebutkan bahwa coping adalah seluruh upaya baik berupa kognitif maupun perilaku untuk menguasai, mengurangi atau meringankan tekanan ${ }^{19}$.
Konsep coping menurut Davison, $G$ adalah bagaimana seseorang berupaya mengatasi masalah atau menangani emosi yang umumnya negatif, dan proses yang digunakan oleh seseorang untuk menangani tuntutan yang menimbulkan stress ${ }^{21}$.

Sementara itu, Pearlin dan Schooler, mendefinisikan coping merupakan konsep yang digunakan untuk menunjukkan berbagai respon terhadap tekanan eksternal kehidupan yang membantu untuk mencegah, menghindari, dan mengendalikan tekanan emosional ${ }^{20}$.

Lazarus dan Folkman membedakan strategi coping menjadi dua, yakni coping yang mengarah pada masalah (problem focused coping) dan coping yang mengarah pada emosi (emotion focused coping. Pembedaan ini berdasar atas dua fungsi coping itu sendiri, coping dapat digunakan untuk menyesuaikan masalah yang menyebabkan stres atau digunakan untuk mengatur respon emosional terhadap masalah ${ }^{21,22,}$.

\section{Hope}

Hope juga merupakan salah satu dari prediktor resiliensi dan salah satu bagian dari psikologi positif. Snyder, dkk memberikan definisi hope sebagai " $A$ Cognitive set that is directed at goal attainment." Lebih lanjut dikatakan oleh Snyder bahwa hope adalah orientasi tujuan di masa depan, keyakinan bahwa tujuan dapat dicapai. Konsep hope didasarkan pada tujuan untuk mencapai kesuksesan (keinginan) yang diraih melalui jalur yang tersedia dan dapat dicapai (cara). Hope dapat menentukan seseorang untuk mencapai prestasi di masa yang lalu, sekarang dan masa yang akan datang. Hope memiliki dua komponen yang saling berhubungan, antara lain: Pertama, persepsi atau cara pandang mengenai kesuksesan berkenaan dengan satu tujuan. Komponen kedua pada konsep hope adalah bahwa perasaan mampu akan menghasilkan suatu cara atau strategi menuju kesuksesan pada suatu tujuan. Dengan kata lain, cara berpikir adalah suatu kapasitas untuk membayangkan suatu cara mencapai tujuan ${ }^{23}$. 


\section{METODE}

Metode penelitian ini adalah menggunakan metode kuantitatif non eksperimen jenis deskriptif analitik dengan design cross sectional .Data dikumpulkan dengan menggunakan instrumen kuesioner yang disusun sendiri oleh Penulis antara lain skala resiliensi, self efficacy, hope, dan strategi coping.

\section{Definisi Operasional}

1. Skala Resiliensi disusun berdasarkan tujuh karakteristik yang dikemukakan oleh Reivich dan Shatte ${ }^{16}$ antara lain: Kemampuan empati, Kemampuan menganalisis penyebab masalah. Memiliki keyakinan diri, Kemampuan meningkatkan aspek positif dengan kategori :

$$
\begin{array}{ll}
\text { Skor } 24-56 & \text { : rendah } \\
\text { Skor } 57-89 & \text { : sedang/cukup } \\
\text { Skor } 90-120 & \text { : tinggi }
\end{array}
$$

2. Self Efficacy disusun berdasarkan tiga dimensi self efficacy antara lain: dimensi tingkat/level,dimensi kekuatan, dan dimensi generalisasi. Instrumen yang akan digunakan adalah skala self efficacy yang akan disusun dengan kategori :

$$
\begin{array}{ll}
\text { Skor } 26-60 & \text { : rendah } \\
\text { Skor } 61-95 & \text { : sedang/cukup } \\
\text { Skor } 96-130 & \text { : tinggi }
\end{array}
$$

3. Hope tersusun atas dua orientasi berpikir, yakni Jalur (pathways/ waypower), dan aksi (agency/ willpower), Luas bidang harapan, dan Spesifikasi. Skala hope akan disusun oleh peneliti dan tim dengan kategori :

Skor 5-11: rendah

Skor $12-18$ : sedang/cukup

Skor $19-25$ : tinggi

4. Strategi Coping, jenis strategi coping yang akan digunakan dalam penelitian ini adalah problem focused coping dan emotion focused coping.

\section{Populasi dan Sampel}

Populasi perawat yang menangani pasien secara langsung di RSPI-SS berjumlah 239 perawat. Teknik pengambilan sampel adalah dengan random sampling. Untuk besaran jumlah sampel dilakukan dengan memakai rumus pengambilan sampel, diambil berdasarkan table morgan. Jumlah sample yang dibutuhkan bila populasinya berjumlah 239 adalah sebanyak 140 orang.

\section{HASIL DAN PEMBAHASAN}

\section{Analisis Data Deskriptif Penelitian}

Sebelum melakukan uji hipotesis, terlebih dahulu disajikan hasil analisis deskriptif data penelitian. Analisis deskriptif dimaksudkan untuk melihat gambaran secara umum data penelitian berupa mean (rerata) dan standar deviasi.

Tabel 1: Deskripsi resiliensi, strategi coping, self efficacy, dan hope

\begin{tabular}{lcccl}
\hline \multicolumn{1}{c}{ Var. } & Frek. & Mean & $\begin{array}{c}\text { Standar } \\
\text { Deviasi }\end{array}$ & Kategori \\
\hline Resiliensi & 103 & 58,71 & 11,05 & Sedang \\
Self & 105 & 69,94 & 11,25 & Sedang \\
Efficacy & 97 & 17,38 & 2,22 & Sedang \\
Hope & 97
\end{tabular}

Hasil analisis berdasarkan penggolongan tingkat resiliensi, self efficacy, dan Hope yang tercantum pada definisi operasional yang telah dibuat oleh peneliti bersama tim yang dibandingkan dengan mean setiap variable pada table 1 di atas didapatkan gambaran bahwa sebagian besar berada pada kategori sedang. Tingkat resiliensi sebagian besar perawat (berjumlah 103 orang) berada pada rentang sedang bawah, sisanya berada pada tingkat yang tinggi dan rendah. Demikian juga dengan self efficacy, sebagian besar perawat (berjumlah 105 orang) berada pada tingkat sedang bawah. Kategori hope juga berada pada rentang sedang, sebanyak 97 orang. Hal ini menunjukkan bahwa pada umumnya perawat di RSPI-SS memiliki kemampuan/ daya tahan dalam menghadapi masalah masih tergolong kurang. Begitu juga dengan gambaran tingkat keyakinan terhadap kemampuan diri dan orientasinya terhadap masa yang akan datang masih cenderung cukup saja. Sementara tuntutan pekerjaan dan kondisi pekerjaan di RSPI-SS menuntut perawat memiliki resiliensi minimal cukup baik 
hingga baik. Maka, bila dihadapkan pada dan tekanan serta goncangan yang berat dalam tugasnya sebagai perawat di Rumah Sakit Sulianti Saroso, dalam waktu bersamaan, akan cenderung kurang tahan.

Tabel 2 . Gambaran Strategi Coping

\begin{tabular}{lcc}
\hline \multicolumn{1}{c}{ Kategori } & Frek & $\%$ \\
\hline Tidak terklarifikasi & 107 & 78.1 \\
Problem focus & 9 & 6.6 \\
Emotional focus & 21 & 15.3 \\
\hline Total & 137 & 100 \\
\hline
\end{tabular}

Dari tabel di atas dapat terlihat bahwa gambaran strategi coping pada sampel penelitian adalah berada pada kategori tuntutan yang demikian besar tidak terklasifikasi yakni sebesar 107 $(78,1 \%)$ responden, disusul dengan strategi coping emotional focus sebanyak 21 orang $(15,3 \%)$ dan yang paling sedikit adalah strategi coping problem focus sebanyak 9 (sembilan) orang (6,6\%). Dalam hal ini cara penyelesaian masalah pada perawat tidak dapat dikemukakan karena masuk dalam kategori tidak terklasifikasi. Yang kedua adalah berfokus pada emosi, hal ini menunjukkan 15\% perawat dalam penyelesaian masalahnya lebih mengutamakan penyelesaian pada emosinya terlebih dahulu, barulah dapat mengambil keputusan yang baik.

\section{Hasil Pengujian Hipotesis}

Hipotesis dalam penelitian ini ada empat. Hal ini dapat dilihat pada tabel 3.

Tabel 3 : Uji Hipotesis

\begin{tabular}{|c|c|c|}
\hline Hipotesis & Deskripsi & Kesimpulan \\
\hline $\mathrm{H} 1$ & $\begin{array}{l}\text { Ada Hubungan antara self efficacy } \\
\text { dengan resiliensi }\end{array}$ & $\begin{array}{l}\text { Didukung data, hipotesis } \\
\text { diterima }\end{array}$ \\
\hline $\mathrm{H} 2$ & $\begin{array}{l}\text { Ada hubungan antara hope dengan } \\
\text { resiliensi }\end{array}$ & $\begin{array}{l}\text { Didukung data, hipotesis } \\
\text { diterima }\end{array}$ \\
\hline $\mathrm{H} 3$ & $\begin{array}{l}\text { Ada hubungan antara strategi coping } \\
\text { dengan resiliensi }\end{array}$ & $\begin{array}{l}\text { Dalam kategori lebih bnyk } \\
\text { masuk ke dalam kelompok } \\
\text { tidak terklasifikasi shg tidak } \\
\text { dapat diuji hipotesis }\end{array}$ \\
\hline $\mathrm{H} 4$ & $\begin{array}{l}\text { Self efficacy, Coping, dan Hope } \\
\text { merupakan predictor resiliensi perawat }\end{array}$ & $\begin{array}{l}\text { Didukung data, hipotesis } \\
\text { diterima }\end{array}$ \\
\hline
\end{tabular}

Penjabaran masing-masing hipotesis tersebut dapat dikemukakan sebagai berikut .

\section{H1. Hubungan antara Self Efficacy dengan Resiliensi}

Dari hasil analisis diperoleh gambaran bahwa terdapat korelasi antara self efficacy dengan resiliensi sebesar $r=$ 0,617 dengan $p=0,000<0,05$. Dengan demikian, terdapat hubungan yang positif dan signifikan antara self efficacy dengan resiliensi. Ini berarti bahwa semakin tinggi self efficacy seseorang, semakin tinggi tingkat resiliensinya. Jadi, perawat yang memiliki kepercayaan atau keyakinan yang tinggi terhadap kemampuan dirinya akan semakin semakin kuat menghadapi masalah dan tekanan-tekanan dalam kehidupan pribadi, pekerjaan, dan kehidupan sosial. Sebaliknya, semakin rendah keyakinan dirinya, perawat semakin kurang tahan dalam menghadapi tekanan dan semakin mudah mengalami masalah psikologis, seperti stress, depresi, dan frustrasi.

Ketika seorang perawat mengukur/ menilai dirinya mampu, maka seberat 
apapun tugas yang harus dikerjakan, ia akan dapat mengerjakan tugasnya tersebut, sebaliknya, perawat yang menilai dirinya tidak mampu atau tidak bisa, maka besar kemungkinannya ia akan benarbenar tidak bisa mengerjakan dan menyelesaikan pekerjaan, kalaupun dikerjakan bisa jadi pekerjaan tersebut sudah menjadi rutinitas saja. Bandura dan Wood, mengemukakan bahwa self efficacy mengacu pada keyakinan akan kemampuan individu untuk menggerakkan motivasi, kemampuan kognitif, dan tindakan yang diperlukan untuk memenuhi tuntutan situasi ${ }^{18}$. Jika motivasinya berkurang, maka cara kerja , sikap kerja, dan perilakunya pasti berubah, tentu saja, daya tahannya terhadap stress pun juga rendah.

\section{H2. Hubungan antara Hope dengan Resiliensi}

Dari hasil analisis diperoleh gambaran bahwa terdapat korelasi antara hope dengan resiliensi dengan dengan $r=$ 0,318 , dengan p $0,000<0,05$. Dengan demikian, terdapat hubungan yang positif dan signifikan antara hope dengan resiliensi. Ini berarti bahwa semakin tinggi hope seseorang, semakin tinggi pula resiliensinya. Artinya, seorang perawat yang memiliki keyakinan bahwa di masa yang akan datang, ia akan sukses, berhasil, dan mencapai cita-cita positifnya akan lebih tahan menghadapi masalah serta tekanan. Karena, seseorang yang focus dan mengejar apa yang ada di depannya, ia akan mengesampingkan segala hambatan demi mencapai sesuatu yang berharga, yang ingin dicapainya di masa yang akan datang. Sebaliknya, orang yang pesimis, tidak memiliki orientasi terhadap masa depan, akan mudah jatuh dan putus asa, yang pada akhirnya, tidak mungkin mengejar citacitanya. Keinginan untuk mengejar karier dan perbaikan hidup yang lebih tinggi pun tidak akan berhasil diperoleh dengan modal harapan yang pas-pasan.

Penelitian ini sejalan dengan penelitian yang dilakukan oleh Gillespie yang menyatakan bahwa terdapat hubungan antara hope dengan resiliensi pada perawat, dan dinyatakan juga bahwa hope merupakan variable bebas dari resiliensi ${ }^{6}$.
Lebih lanjut diterangkan dalam penelitian tersebut, bahwa seorang perawat memiliki harapan bahwa dirinya bisa mendapatkan keadilan, dukungan dan kesempatan untuk mengembangkan diri. Dengan harapan tersebut, seorang perawat akan berusaha untuk mencapainya dengan melalui jalur-jalur usaha tertentu yang dapat ditempuhnya, sehingga ini akan meningkatkan ketahanannya dalam mengatasi masalah.

\section{H3. Hubungan antara Strategi Coping dengan resiliensi}

Dalam analisis deskripsi, tingkat strategi coping sebagian besar berada pada kategori tidak terklasifikasi, Dengan demikian, tidak dapat dilakukan analisis selanjutnya, yakni uji hipotesis yang menguji hubungan antara strategi coping dengan resiliensi.

\section{H4. Self efficacy, Coping, dan Hope merupakan predictor resiliensi pada perawat}

Berdasarkan analisis data, hipotesis "Ada hubungan antara strategi coping, self efficacy dan hope dengan resiliensi secara bersama-sama" dapat diterima, karena terbukti dari output model summary diperoleh $\mathrm{R}$ (koefisien korelasi ganda)= 0,635 , dengan $R$ Square $=0,403$. Skor tersebut menunjukkan bahwa secara bersama-sama ketiga variabel yang secara signifikan memberikan sumbangan (prediktor) terhadap resiliensi sebesar $40,30 \% \quad(0,403 \times 100 \%), \quad$ sedangkan sisanya sebesar 59,7 ( $100 \%-40,3 \%)$ disumbangkan oleh faktor lain yang tidak diteliti. Dengan $R=0,635$ dan $p=$ $0,000<0,005$, dengan kontribusi $(R \mathrm{Sq})=$ $40,30 \%$ ketiga variabel prediktor (strategi coping, self efficacy dan hope) secara bersama-sama dianggap dapat memprediksikan resiliensi dengan baik.

Telah disebutkan di atas bahwa ketiga prediktor secara bersama-sama berkorelasi dengan resiliensi yakni sebesar 40,30\%. Namun, dalam hasil analisis kontribusi dari ketiga variabel prediktor tersebut hanya variable selfefficacy dan hope yang memberikan kontribusi pada resiliensi. Kontribusi untuk self efficacy terhadap resiliensi adalah sebesar $38,1 \%$ dan sisanya yakni $2,2 \%$ 
adalah kontribusi dari variable hope, sedangkan strategi coping tidak memberikan kontribusi terhadap resiliensi.

Kemampuan menilai diri, memiliki harapan yang positif akan diri di masa yang akan datang, dan kemampuan menyelesaikan masalah akan meningkatkan kemampuan perawat menghadapi masalah sebesar dan seberat apapun. Namun demikian, resiliensi tidak hanya berhubungan dengan ketiga faktor tersebut di atas, namun juga faktor lain yang tidak dimasukkan ke dalam penelitian ini, antara lain misalnya : faktor kepribadian, dukungan sosial (manajemen, atasan, dan rekan kerja), dan sebagainya.

\section{Hasil Analisis Tambahan}

Variabel demografik sebenarnya tidak diikutkan dalam hipotesis penelitian sehingga tidak merupakan keharusan untuk menganalisisnya. Namun, karena data-data yang dikandung dalam variabel demografik ini cukup penting, dilakukan uji korelasi antar semua variabel demografi dengan resiliensi. Untuk mengetahui perbedaan antar kelompok digunakan teknik perhitungan statistik independent sample t-test. Hasilnya menunjukkan terdapat perbedaan antara masa kerja dengan resiliensi di RSPI-SS dengan korelasi sebesar 0,022, yang berarti semakin lama masa kerjanya semakin tinggi tingkat resiliensi subyek Artinya, masa kerja yang semakin lama dapat meningkatkan ketahanan seseorang di dalam menghadapi tekanan. Hal ini mungkin disebabkan adanya proses penyesuaian diri terhadap bidang pekerjaan dan semakin berpengalaman sehingga dapat meningkatkan resiliensi pada perawat di dalam pekerjaannya.

\section{KESIMPULAN DAN SARAN}

\section{Kesimpulan}

Berdasarkan hasil uji hipotesis, dapat dinyatakan bahwa : (1) terdapat hubungan yang signifikan dan berarah positif antara self efficacy, hope, dan strategi coping secara bersama-sama dengan resiliensi; (2) terdapat hubungan yang signifikan dan berarah positif antara self efficacy dengan resiliensi; (3) terdapat hubungan yang signifikan dan berarah positif antara hope dengan resiliensi;

Berdasarkan perhitungan deskriptif didapatkan hasil bahwa tingkat resiliensi pada perawat di RSPI-SS, berada pada kategori sedang bawah. Hasil analisistambahan didapatkan hasil bahwa ada hubungan antara masa kerja dengan Resiliensi pada perawat di RSPI-SS.

\section{Saran Praktis}

a. Memberikan tantangan-tantangan kecil kepada perawat, sehingga perawat mendapatkan pengalaman berhasil maupun gagal dalam melakukan suatu tugas atau tantangan. Pengalaman demi pengalaman yang dimiliki akan meningkatkan kepercayaan diri sehingga siap dengan segala tantangan atau tugas lain yang lebih kompleks dari sebelumnya.

b. Perawat diajak serta untuk mengembangkan tujuan atau orientasi masa depan dan apa peran yang dapat mereka ambil untuk memberikan kontribusi kepada institusi. Jika mereka diberikan kepercayaan bahwa pelayanan mereka dan segala yang mereka lakukan untuk rumah sakit akan memberikan kontribusi dan manfaat yang besar bagi banyak pihak, mereka akan terdorong untuk mau mengambil tantangan dan pencapaian yang positif di masa yang akan datang.

c. Memberikan sarana konseling bagi perawat

d. Intervensi resiliensi beserta prediktorprediktornya dapat digunakan oleh perawat sebagai bagian dalam pelayanan terhadap pasien.

e. Dilakukan screening awal bagi calon perawat yang baru direkrut oleh RSPI Prof. Dr. Sulianti Saroso.

f. Mengikut-sertakan seluruh perawat dalam berbagai pelatihan untuk meningkatkan kompetensi dan wawasannya tentang penyakit dan pekerjaannya. 


\section{DAFTAR PUSTAKA}

1. Bandura, A. "Self-efficacy Mechanism in Human Agency", Journal American Psychologist, Vol 37. 1982

2. Bandura, A. Self Efficacy Overview. New York : Stanford Academic Press.1997.

3. Baron\& Byrne, Donn. Social Psychology. Massachuteetts: Allyn \& Bacon.1997.

4. Davis, N.J. Resilience \& School Violence Prevention: Research-based program. National Mental Health Information Center.1990.

5. Fitri Fausiah. Psikologi Abnormal Klinis Dewasa. Jakarta: Universitas Indonesia.2005

6. Gillespie, Brigid, M."The Predictors of Resilience in Operating Room Nurses". Journal American Psychologis . 2007.Vol 37.

7. Grotberg, E. A Guide to Promoting Resilience in Children: Strengthening The Human Spirit, Benard Van Leer Fondation.1995.

8. Grotberg, E. Tapping Your Inner Stregth. New Harbinger Publication, Inc.1999.

9. Herry Tjahjono. Extra Ordinary Way. Jakarta: Penerbit Grasindo.2007.

10. http://www.depkes.go.id/downloads/S $\mathrm{KN}+$.PDF.

11. Holman, S.E.. "Social Psychologycal Resources and Adaptation". Review Of General Psychology. Jurnal Provitaevol 2, no 1,Mei , 2006.

12. Klohnen, E.C."Conseptual Analysis and Measurement of The Construct of Ego R Resilience", Journal of Personality and Social Psychology.1996

13. Lopez,S \& Snyder.C.R. Positive Psychologycal Assessment. Washington DC : American Psychologycal Association.2003

14. Lopez,S \& Snyder,C.R. Positive Psychologycal : The Scientific and Practical of Human Strengths. New York : Sage Publications, Inc.2005

15. Reivich,K,. The Resilience Factor. NewYork: Random House inc.2002.

16. Schultz, D.Psikologi Pertumbuhan. Jakarta: Gunung Mulia.2002.
17. Davison, G \& Neale, J. Psikologi Abnormal. Jakarta : PT.Raja Grafindo Persada.2006.

18. Ghufron, M.Teori Piskologi, Jakarta : Ar-Ruzz Media.2010.

19. Rice, Phillips L. Stress and Health. United stade of America. Broke/cole Publishing company.1999.

20. Billings, A.G., \& Moos, R.H. Conceptualizing and Measuring Coping Resourcesand Processes. Dalam Goldberger, L., \&Breznitz, S. (Eds.), Handbook of stress : Theoretical and clinical aspects (212228). New York : Macmillan Publishing. 1982.

21. Atkinson, R.L., Atkinson, R.C., Smith, E.E., \&Bem, D.J.Introduction to psychology(11th.). Fort Worth : Harcourt Brace College.1993.

22. Sarafino, E. Health psychology : Biopsychology interaction (2nd). New York : John Willey and Sons. Inc. 1994

23. Chang, L. \& McBride-Chang, L. The factor structure of the LOT. Educational and Psychological Measurement, 56, (2) 325-329.1996.

24. Format elektronik diakses pada http:// kolangmanise.blogspot.com/2012/11/ hubungan-stress-perawat-dan-bebankerja.html tanggal 1 sepetember 2014

25. Freudenberger. "Staf burnout", Journal of Social Issues, 30(1), pp. 159-165. 1974 